するなど，先端技術開発を通じた地域経済の活性化を も図っている。

さらに，今後とも国立試験研究機関として期待され る役割を十分に果たしていく必要があるとの観点か ら, 現在，次のような体制整備を行っている.

第 1 に, 進展の著しい技術革新に対応した研究開発 体制の整備のため, 各試験所の機構改革を進めている.

第 2 に, 学際領域に属する試験研究の効率的推進を 図るため, 各試験研究所間の連携を一層強化していく こととしている.
第 3 に，共同研究，技術相談，依頼分析等の地域産 業界の技術ニーズに積極的に対応するため, 地域試験 所の技術相談所を改組し，技術交流センターを設置し たところである。

\section{6. むすび}

以上に，工業技術院に打ける基礎研究及び基盤技術 開発のための体制作りの概略について述べた。今後の 当院の活動につき，一層の御理解と御鞭撻を賜るよう 扮願いする次第である。

\title{
国際電気通信基礎技術研究所 ${ }^{*}$
}

\section{吉川憲昭**}

\section{1. 設立の背景と経緯}

我が国の電気通信分野の研究開発のレベルが，世界 一流の域に達し，その技術力で国際社会をリードして いる現在, 自ら先行指標を開拓することが我が国の国 際的責務となって来ている。これまで我が国は特に製 品開発の面で世界をリードしてきたが，将来の飛躍的 な技術革新の芽となる基礎研究に関する国際的な寄与 はあまりなされていなかった。

特に電気通信は，高度情報社会において国家的に根 幹を担うものであり，この分野で想像性に富む基礎・ 先端技術の国家的な競争力を強化することが最も必要 である。

このような独創的な基礎研究を各企業が独立に進め るのは，リスクが大きく効率も悪くなる。このため, 競争体制を維持しつつ産・学・官が協力して，その技 術力の結集を図り，我が国における電気通信分野の基 礎的技術ポテンシャルの向上を促進する必要がある。

このような背景から, 昭和 59 年秋ころ, 電電公社の 民営化に伴ら株式処理もあって, 郵政省から電気通信 振興機構の設立とその中核機関として電気通信基礎技 術研究所の構想が発表され，電気通信を支える重要技 術として, 光通信基礎技術, 宇宙通信基礎技術, マン・ マシンインタフェース基礎技術, 自動翻訳電話システ ムの開発がとり上げられた。

一方，関西では，国土庁を中心として京都，大阪，

* 原稿受付 昭和 61 年 11 月 20 日

** (株)国際電気通信基礎技術研究所 (ATR)（大阪市東区城見 2-1-61)
奈良の 3 府県にまたがる丘陵地帯に関西文化学術研究 都市を建設する構想が進められていたが，この構想の 具体化を促進するため, 関西経済連合会を中心に上記 研究所の誘致が進められた。

昭和 61 年 1 月基盤技術研究促進センターの出資募 集に応募し，出資決定を受けて 4 つの研究開発会社が 発足した.

現在，各研究開発会社は，大阪ビジネスパーク（大 阪市東区) のッイン 21 ビルで研究を開始しているが, 昭和 63 年度には, 現在建設が進められている関西文化 学術研究都市の中核的施設として, 京都府精華町に移 る予定である。

\section{2. 研究所のねらい}

（1）電気通信，特に人間科学，情報科学，光電波科 学, 物性科学等の分野に招ける基礎的, 独創的研究の 推進.

（2）産・学・官の共同研究体制の確立により, 知的 資源の有効利用を図るとともに，開かれた研究所とし て研究交流を推進する。

（3）電気通信分野の国際性,我が国の国際社会への 貢献といら観点から, 研究開発面に打ける国際協調体 制の確立を図る。

\section{ATR の形態}

ATR は, ATR インターナショナルを核として, 複 数の研究開発会社がその施設に収容される研究グルー プを構成しておう，研究開発の進展に応じて拡大され 
る.すなわち, 総合的に研究推進事業を行らとともに, 基礎研究を行ら研究開発会社に対し, 土地・建物を貸 与するなど物的, 人的, 資金的に支援を行う ATRイン ターナショナルと, この支援の下に具体的プロジェク 卜研究を行う 4 つの研究開発会社から構成されてい る.

ATR の研究員は, 産・学・官に開かれた研究所とい 設立の主旨に基づき, NTT, KDD, NHK 等出資企 業からの出向者, プロパー職員, 大学等からの研修研 究員, 外国からの客員研究員, 研究の支援を行ら研究 技術員等により構成される。研究員数は, 61 年度末約 100 名, 70 年度末約 280 名を予定している。

資本金は，ATRインターナショナルは約 200 億円 (昭和 64 年度までに産業界からの出資により調達), 4 つの研究開発会社は総額 700 億円(昭和 70 年度までに 7 割を基礎技術研究促進センターから, 3 割を ATR イ ンターナショナルを含む産業界からの出資により調 達)である。

\section{ATR グループの研究内容}

1）ATR 通信システム研究所

通信システムをより高機能，高信頼にし，かつ，だ れでも簡単な操作で使えるよう, すなわち, 人間主体 のネットワークにするための基礎研究をテーマとして いる。このため, 通信ソフトウェアの自動作成, 高度 化セキュリティ, 三次元画像の自動入力法や知能処理 等の研究を行う.

2) ATR 自動翻訳電話研究所

自動翻訳電話に必要な要素技術の基礎研究をテーマ としている。不特定な話し手の音声を聞き分けて認識
する音声認識，異なる言語間の変換を高速に行う機械 翻訳, 変換した言語を自然な音声で表現する音声合成 等の要素技術について高度化のための基礎研究を行 万.

3) ATR 視聴覚機構研究所

視聴覚に関する人間科学的基礎研究をテーマとして いる，素人でも容易に使うことのできる高度情報通信 システムを実現するための基礎を担らマン・マシンイ ンタフェース技術の確立を目指し, 工学と心理学の両 面からの研究を行ら.

4) ATR 光電波通信研究所

新周波数帯の開発等を目指した光電波通信に関する 基礎研究をテーマとしている。また, 将来の超高速大 容量通信を可能にする新素子等デバイス面からの基礎

さらに将来への展開として

(1) 物性物理, バイオェレクトロニクスの研究

(2) 標準化を目指したシステム概念の研究

(3) 研究所の成果に基づく端末機器への応用に関す る研究

(4) 光と電波領域間の未開拓波長域の可能性に関す る研究

についての研究テーマとして取り組む可能性を検討す ることとしている.

ATR グループは我が国を代表する企業から一流の 研究者の出向者を中心に比較的恵まれた研究環境の下 に一企業の営利目的のためでなく, 豊かになった我が 国の責務として産・学・官の協力を得て, 21 世紀に向 けた創造的な研究開発に一歩踏み出そうとしている.

ATR に対するこのような社会の期待を現実のもの とするために, 今後各方面の支援育成を打願いしたい。

\section{大阪大学レーザー核融合研究センター*}

\section{中山千代衛 $* *$ 中井貞雄 ${ }^{* *}$}

独創的な先進科学技術は, 我が国の将来の存立がか かわる基盤である，外国からの導入技術の改良と応用 により成長してきた我が国の産業技術は，これ以上の 外国依存を継続しえない状況となってきた。内部から わき出る発展要因に支えられた創造的な研究開発の推 進が必要である。このためにこそ基礎研究の重視が必

* 原稿受付 昭和 61 年 10 月 20 日

**大阪大学レーザー核融合研究センター（吹田市山田丘 2-6)
要なのである.

我が国のエネルギー自給を達成し，国家としての将 来展望を確立しょうとするレーザ核融合エネルギー開 発研究は，それ自体が高度科学技術の広範な分野に基 盤を損いている，従ってその推進は，我が国に特に必 要とされる独創的な科学技術発展の牽引力として大き な期待が寄せられている。

核融合の研究には周知のように, 磁気閉じ込め方式 